九州大学学術情報リポジトリ

Kyushu University Institutional Repository

\title{
Demon Roof Tiles: A Study of the Dazaifu Type Onigawara Style I-A
}

Igata, Susumu

Bogel, J. Cynthea

DeWitt, E. Lindsey

https://doi.org/10.5109/2231636

出版情報: Journal of Asian Humanities at Kyushu University. 4, pp.109-125, 2019-03. Kyushu University, School of Letters, Graduate School of Humanities, Faculty of Humanities バージョン:

権利関係 : 


\title{
Demon Roof Tiles: A Study of the Dazaifu Type Onigawara Style I-A
}

\author{
SUSUMU IGATA \\ TRANSLATION BY CYNTHEA J. BOGEL AND LINDSEY E. DEWITT
}

\section{Translators' Preface}

Within the large surviving body of fired earthenware roof tiles from ancient Japan, among the most striking are the expressive tiles known as onigawara 鬼瓦, "demon tile." High- and low-relief onigawara show a demon or ogre's face, sometimes with all or part of a simplified torso. Its exaggerated brow and eyes, face creased by a scowl, and gaping mouth with bared fangs are cleverly arranged on a distinctive tile shape that in the final product melds function with form. Demon tiles, still in use today, were typically placed on the outer ends of the main roof ridge or on the lowermost end of various descending ridge forms (see figure 7), where they would be most visible from the ground. This article considers distinctive demon tiles from Dazaifu, northwest Kyushu, where a regional government office was in place from the end of the seventh century through the Nara (710-784) and beyond the Heian (794-1185) period, when Nara and Kyoto were capitals. The term "regional" may conjure an image of something less than significant. The north of Kyushu, ${ }^{1}$

This article is based on Igata, "Dazaifu-shiki onigawara kō: I-shiki A o chūshin ni." Permission to adapt and publish the article and illustrations is given by the publisher, Koshi Shoin (its trademark name) 高志書院 (Kōshi Shoin). Additional footnotes have been however, was the "gateway to Asia" for centuries, second in historical significance during the late seventh through twelfth century only to the area around the capitals. Envoys and other important visitors from kingdoms on the Korean peninsula or the Chinese Sui (581-618) and Tang (618-907) dynasty courts, among others, were required to report to Dazaifu after they entered the bay of Hakata, modern Fukuoka. Buddhist monks, merchants, and other travelers visited Dazaifu to pray for a safe journey, complete paperwork, or wait for a ship to be repaired. The appearance and visual history of the Dazaifu onigawara type of roof tile embodies this fascinating history and, as the author argues, embodies characteristics and showcases techniques both distinct from and dependent on the influence of the Korean peninsula and Tang-dynasty tiles, and those of the Heijō capital (Nara).

added to the English adapted translation. For the readers' ease of reference, the translators have indicated the original note number in brackets (e.g., [1]), at the end or midway through the note.

1 Northern Kyushu (Kyūshū hokubu 九州北部 or Hokubu Kyūshū) has had constant contact with other parts of East Asia since ancient times. Until 1963, when the city of Kitakyūshū 北九州, "north Kyushu" or "northern Kyushu," was formed, the area encompassing all or part of the modern prefectures of Fukuoka, Saga, Kumamoto, Oita, and Nagasaki was referred to by the same name, Kitakyūshū. 


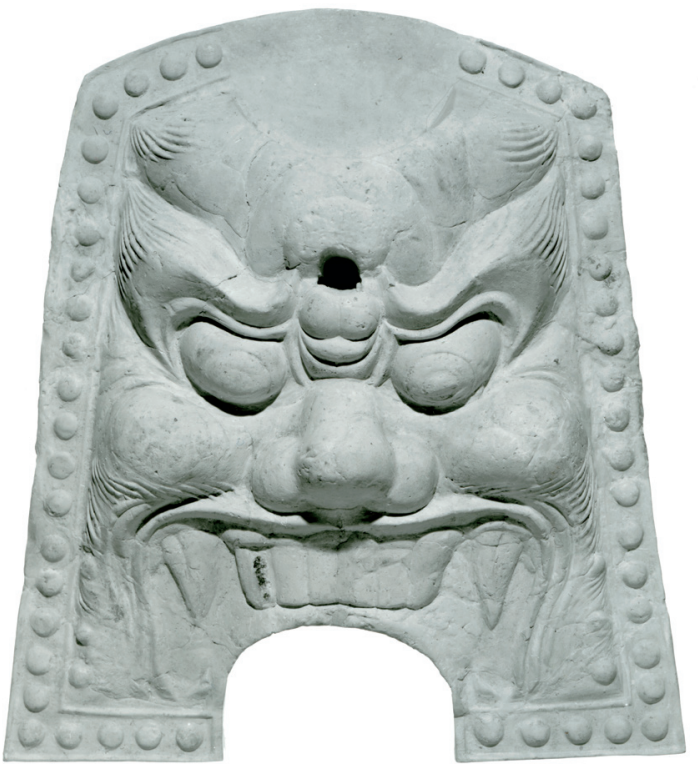

Figure 1. Roof tile, Dazaifu Type Onigawara Style I-A. 720 s to mid 8th c., Nara period. Fired earthenware. Collection Kyushu Historical Museum. Note: all figures except 7, 12, and 17 are reproduced from Igata, "Dazaifushiki onigawara kō: I shiki A o chūshin ni," with permission of the publisher.

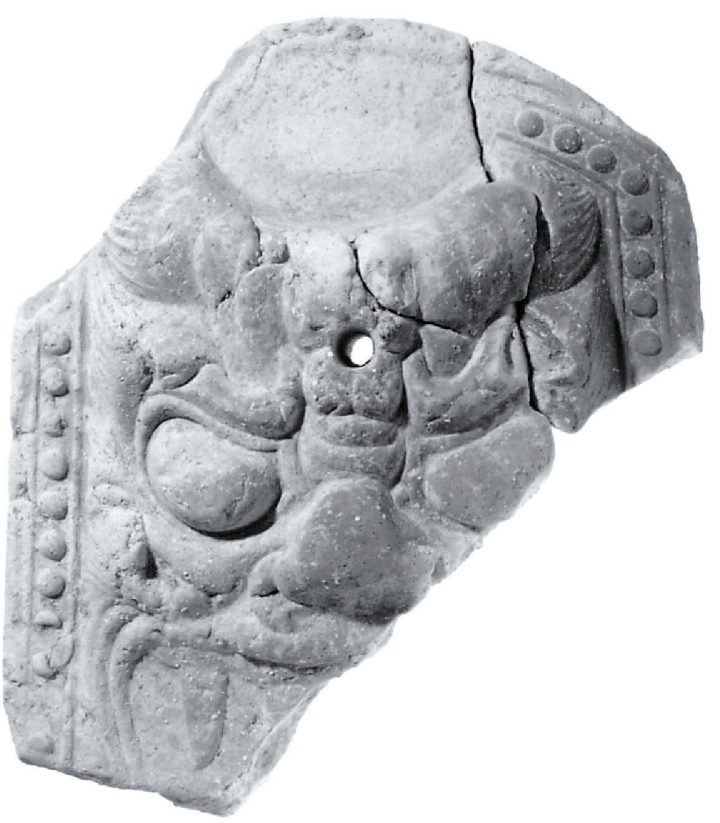

Figure 3. Roof tile, Dazaifu Type Onigawara Style II. 8th c., Nara period. Fired earthenware. H $44.5 \mathrm{~cm}$. Collection Kyushu Historical Museum.

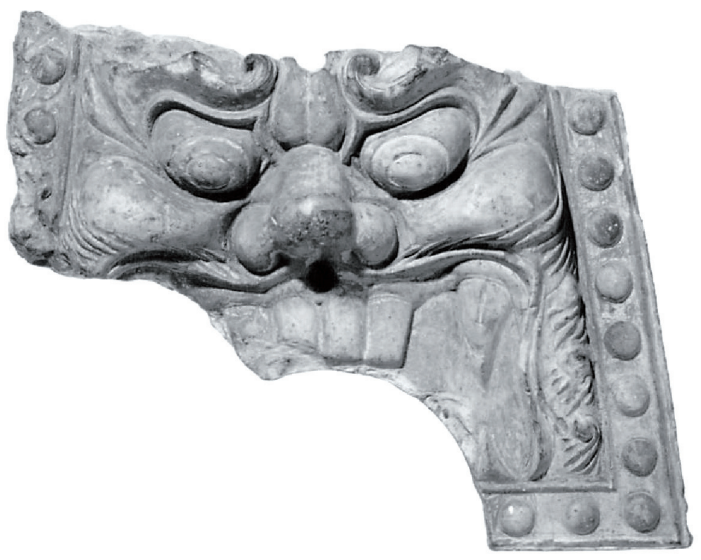

Figure 2. Roof tile, Dazaifu Type Onigawara Style I-B. 8th c., Nara period. Fired earthenware. H 34 cm. From Nikkanji, Dazaifu, Fukuoka Prefecture.

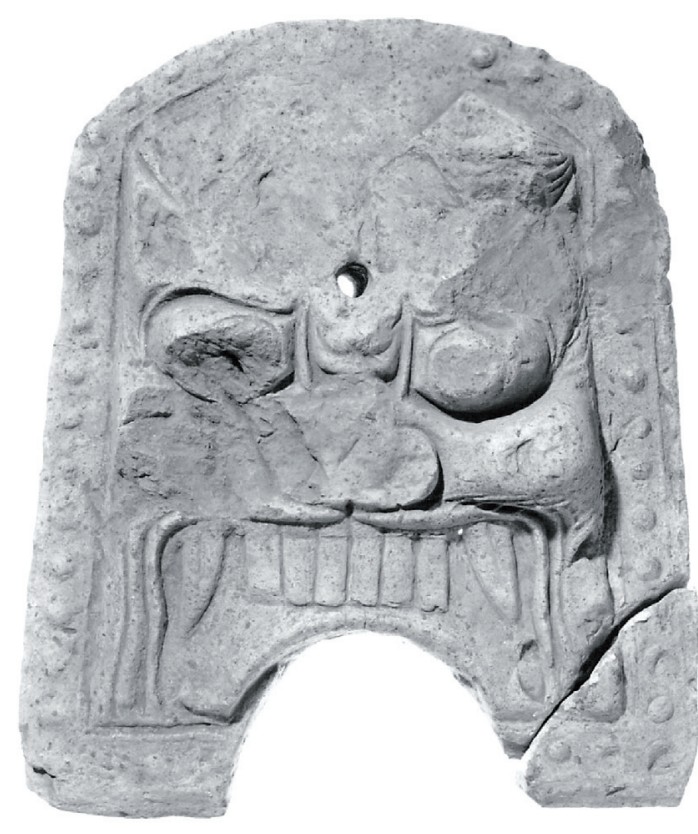

Figure 4. Roof tile, Dazaifu Type Onigawara Style III. 8th c., Nara period. Fired earthenware. H $38.2 \mathrm{~cm}$. Collection Kyushu Historical Museum. 

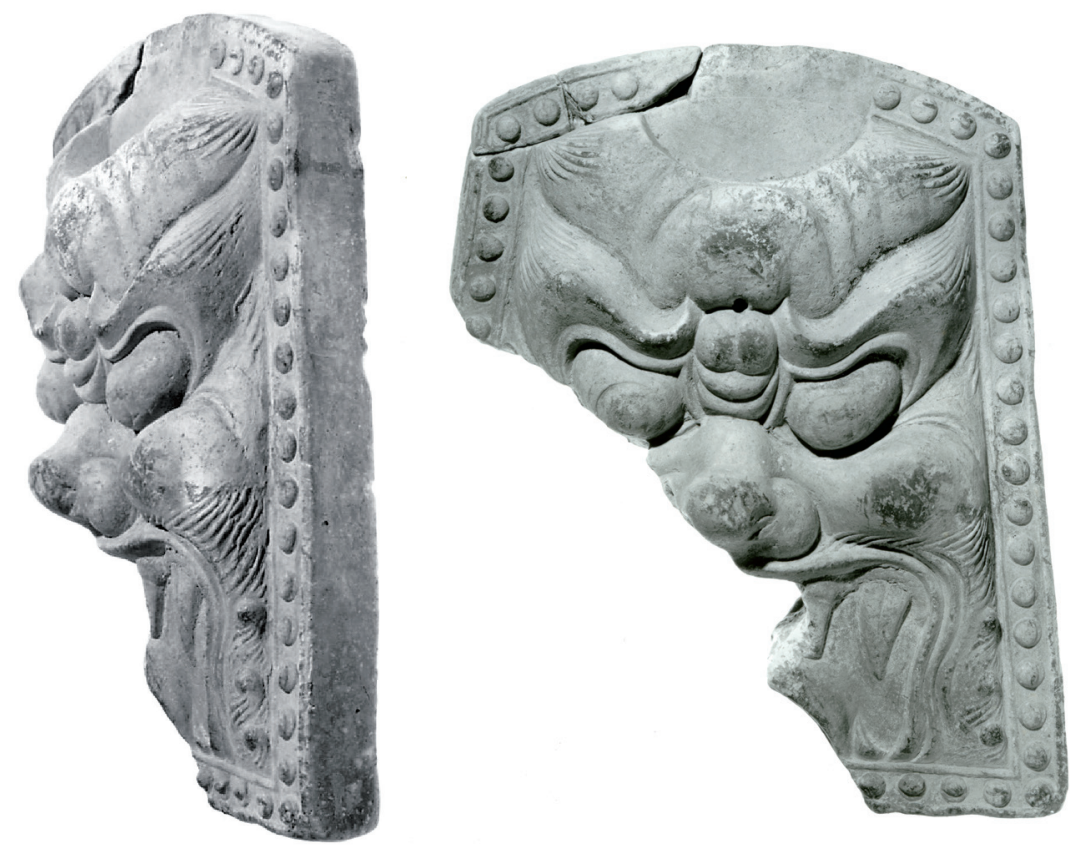

Figure 5. Roof tile, Dazaifu Type Onigawara Style I-A. 720s to mid 8th c., Nara period. Fired earthenware. H: $48.7 \mathrm{~cm}, \mathrm{H} 44.4 \mathrm{~cm}$ to the shoulder/corner, W of shoulder $35 \mathrm{~cm}$, thickness (maximum) $13.4 \mathrm{~cm}$. Collection Kyushu Historical Museum.

\section{Introduction}

Onigawara 鬼瓦 roof tiles portraying an ogre or demon have been excavated at Dazaifu's landmark historical sites and ruins (Dazaifu Shiseki 大宰府史跡), in particular at the Dazaifu Government Office (Dazaifu Seichō 大宰府政庁). Works similar in style have also been found throughout northern Kyushu at or near government offices, temples, and shrines in the premodern provinces of Chikuzen 筑前, Chikugo 筑後, Hizen 肥 前, northern Higo 肥後, Bungo 豊後, and Buzen 豊前. 2 Together these demon tiles constitute a group referred to as the “Dazaifu lineage" (Dazaifu kei 大宰府系); the category also includes tiles excavated from the southern part of Kyushu, far from Dazaifu. Given this range of distribution, it becomes clear that the "Dazaifu Type demon tile" exerted influence throughout all of Kyushu, justifying the designation of this type. The earliest of the Dazaifu Type Onigawara, named, literally, "Dazaifu Style Demon Tile I Style A" (Dazaifu shiki onigawara I

2 Reports on the Dazaifu historic sites and Dazaifu Type Onigawara roof tiles are compiled in Kyūshū Rekishi Shiryōkan, Dazaifu Seichō ato. [n1] shiki A 大宰府式鬼瓦I式A), is the subject of this article. It is rendered here as "Dazaifu Type Onigawara Style I-A" and similar names to fit better with English nomenclature.

Today, Japanese archaeologists and art historians broadly divide Dazaifu Type demon tiles into three styles: Style I (figures 1, 2, and 5), Style II (figure 3), and Style III (figure 4 ). ${ }^{3}$ Even though the production dates for the three styles differ, we may conclude that all three date to the Nara period. Style I is the fundamental Dazaifu Type tile; it was probably manufactured during the second phase of construction at the Dazaifu Government Office, that is, during the first quarter of the eighth century, making it the oldest of the three. Dazaifu Type onigawara are divided into groups A and B based on their size, with Style I-A the larger of the two. The sophisticated mode of representing the demon

3 These names and styles follow Morimitsu, "Nihon kodai no kimenmon onigawara," whose method other researchers have followed. Kyūshū Rekishi Shiryōkan, Dazaifu Seichō ato additionally cites Oda, "Kyūshū ni okeru Dazaifu-kei kogawara no tenkai (4)," and Kurihara, "Dazaifu-shiki onigawara," and seems to regard those three works as the major preceding studies. The present research is based on those same three essays and, in addition, Kameda, "Kogasen yori mita Dazaifu to Chōsen." [n2] 
with realistic modeling distinguishes Style I-A. In keeping with this assessment, when both Style I-A and Style I-B were deployed on a roof, Style I-A appears to have been the tile used for the crowning roof ridge (ommune 大棟), while Style I-B was used for the descending corner ridge (kudarimune 降棟) and corner ridges (sumimune 隅棟). ${ }^{4}$

Style I-A has been excavated only at Dazaifu sites, save one example, and the majority of tiles have been found at the site of the Dazaifu Government Office. Because the use of this onigawara style was essentially limited to the central part of Dazaifu and demonstrates a higher standard of craftsmanship than other Dazaifu types, Style I-A has been treated not only as representative of the Dazaifu Type but has come to symbolize Dazaifu itself. There has been very little study of this important type of artifact to date. ${ }^{5}$ Building on the author's previous studies on Dazaifu demon tiles, this article focusses on Dazaifu Style I-A, and in doing so hopes to cast further light on onigawara - and on Dazaifu as well.

\section{Dazaifu Type Onigawara Style I-A Tiles}

Let us return now to some specifics about Style I-A. Tiles in this category are on average $48.5 \mathrm{~cm}$ high, bottom width $43.5 \mathrm{~cm}$, shoulder width $35 \mathrm{~cm}, 5 \mathrm{~cm}$ thick at the edges, and $15 \mathrm{~cm}$ at the thickest part. ${ }^{6}$ Apart from

4 Oda, "Kyūshū ni okeru Dazaifu-kei kogawara no tenkai (4)," p.12. Style I-B was used independently outside the Dazaifu sites. In those cases, either shibi 鴟尾 (decorative roof tiles on both sides of the ridge) or Style I-B were likely used for the omune. [n3; nb: the above carries a correction to original note 3] Note that the corner ridge can be on the same line as the descending corner ridge or at an angle to it (perpendicular or other). For images of onigawara placement and definitions of other architectural components, see JAANUS http://www.aisf.or.jp/ jaanus/deta/k/ kudarimune.htm and http://www.aisf.or.jp/ jaanus/deta/t/tsumakudarimune.htm.

5 Major articles on Dazaifu Style onigawara roof tiles by the author include "Dazaifu-shiki onigawara shōkō"; "Dazaifu-shiki onigawara shōkō hoki"; and "Dazaifu-shiki onigawara: I-shiki A." [n4]

6 Kurihara, "Dazaifu-shiki onigawara," p. 581. The dimensions of other styles are as follows (numbers in parentheses indicate restored sizes):

Style I-B: Height: $34 \mathrm{~cm}$; Bottom width: $(33.5 \mathrm{~cm})$; Thickness: $10 \mathrm{~cm}$

Style II: Height: $(44.5 \mathrm{~cm})$; Shoulder width: $27.5 \mathrm{~cm}$; Bottom width: $(34 \mathrm{~cm})$; Thickness: $9.5 \mathrm{~cm}$

Style III: Height: $38.2 \mathrm{~cm}$; Shoulder width: $(30.2 \mathrm{~cm})$; Bottom width: $36.1 \mathrm{~cm}$; Thickness: $(11.3 \mathrm{~cm})$

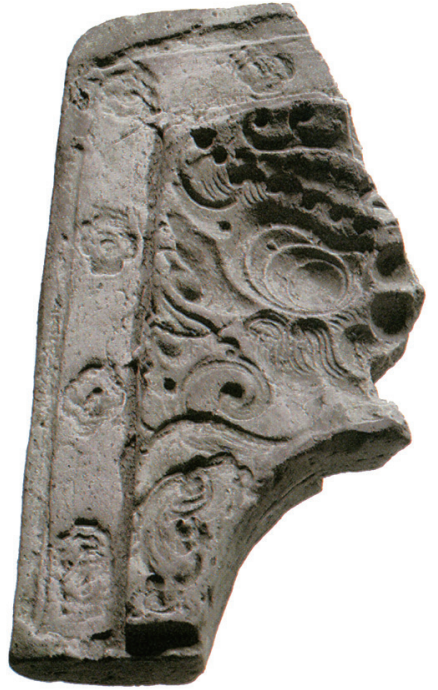

Figure 6. Mold for a demon tile. 7th-8th c., Unified Silla period. Fired earthenware. H $21.5 \mathrm{~cm}$. Collection Gyeongju National Museum. Reproduced from Kungnip Kyŏngju Pangmulgwan, Silla wajŏn, p. 403 , no. 1321.

one piece excavated from a Chinese-style mountain castle, Itojō 怡土城, in the city of Itoshima, Fukuoka Prefecture, the tiles have been excavated mainly from the Dazaifu Government Office, with additional findings at the ruins of Mizuki Castle 水城, Ōno Castle 大 野城, and the convent Chikuzen kokubunniji 筑前国 分尼寺. Figure 5, the best-known example, designated an Important Cultural Property ( $j u \bar{u} y \bar{o}$ bunkazai 重要 文化財), was reportedly found in a field north of the Dazaifu Government Office site at the end of the Taishō period (1912-1926). The surface of the Itojo tile is severely damaged, having deteriorated not only through use and due to preservation issues but also as a result of the use of a worn mold at the start, the surface of which had deteriorated from repeated use for tile making. I surmise that the production of Style I-A had become essentially obsolete contemporaneous with the building of Itojō (castle), for which construction started in Tenpyō Shōhō 天平勝宝 8 (756) and ended in Jingo Keiun 神護景雲 2 (768). Clearly, the production of Style I-A was concentrated around the time of the second phase

\footnotetext{
Style I-A, figure 5 was measured by the author as follows: Height: $48.7 \mathrm{~cm}$; Height to the shoulders: $44.4 \mathrm{~cm}$; Width of shoulder: $35.0 \mathrm{~cm}$; Thickness (maximum): $13.4 \mathrm{~cm}$; Thickness of edge: $4.0-4.8 \mathrm{~cm}$. The top edge tends to be a little thinner than the bottom edge. [n5]
} 
of construction at the Dazaifu Government Office, as we have noted. There, its use differed from that of other tile types. We can thus hypothesize that Style I-A was featured at Dazaifu's landmark buildings. In trying to pinpoint the specifics of when Style I-A began to be produced and how long its use continued, we can reference debates about the dates of the second phase of construction at the Dazaifu Government Office to conclude that the likely origins of Style I-A fall at the end of the first quarter of the eighth century, in the 720s, and that production ended no later than the middle of the eighth century.

As regards color, the surface is ash-gray or grayish white and the interior is off-white, but some tiles with pure white surfaces have been found. Fine clay mixed with a small quantity of sand is used for the tiles. We can determine from the three-dimensionality of the whole and the extremely varied thickness of various parts that clay was placed into the mold layer by layer. ${ }^{7}$ As figure 5 shows on the angled view, the lateral surfaces of the demon tiles are smooth; in general the tiles are cast with a smooth backside as well, although a rope pattern can be seen on one excavated example. ${ }^{8}$ The process seems to have been as follows: clay was placed in the mold layer by layer, then removed immediately, after which the front (face) side was cleaned up and a hole made between the eyebrows. The tiles were then dried and fired at a relatively low temperature.

The clay mold is thought to have been created using a three-dimensional prototype (such as another tile) to which details were added by hand before firing. Another theory proposes that a wooden mold was created for the process. ${ }^{9}$ Wood might well have been used for

7 Regarding production techniques, in addition to visual inspec tion of numerous fragments excavated from the Dazaifu site, I draw from the advice of Katō Kazutoshi, who conducted research of Dazaifu Style onigawara with a CT scanner at Kyushu Historical Museum. On this research, please refer to the catalogue Kyūshū Rekishi Shiryōkan, Dazaifu o saguru saiensu, headed by Katō. [n6]

8 This was found during the sixth survey of Dazaifu (大宰府史跡の第 6 次調查); see Kurihara, "Dazaifu-shiki onigawara," p. 583; Kyūshū Rekishi Shiryōkan, Dazaifu Seichō ato, p. 213. The author of the relevant passage is Kurihara. [n7]

9 Kurihara, "Dazaifu-shiki onigawara," p. 591. On the other hand, in a column called "Jiman no ippin" 自慢の逸品 in the evening edition of Nishinippon shinbun 西日本新聞, 1996.10.12, Kurihara introduces Dazaifu Type onigawara as a noteworthy attraction of the Kyushu Historical Museum. He states that a negative mold made of sand was found among demon roof tiles in Silla (see also note 12 below), "thus it may be the case that Dazaifu Type demon tiles were produced by creating a negative mold in sand
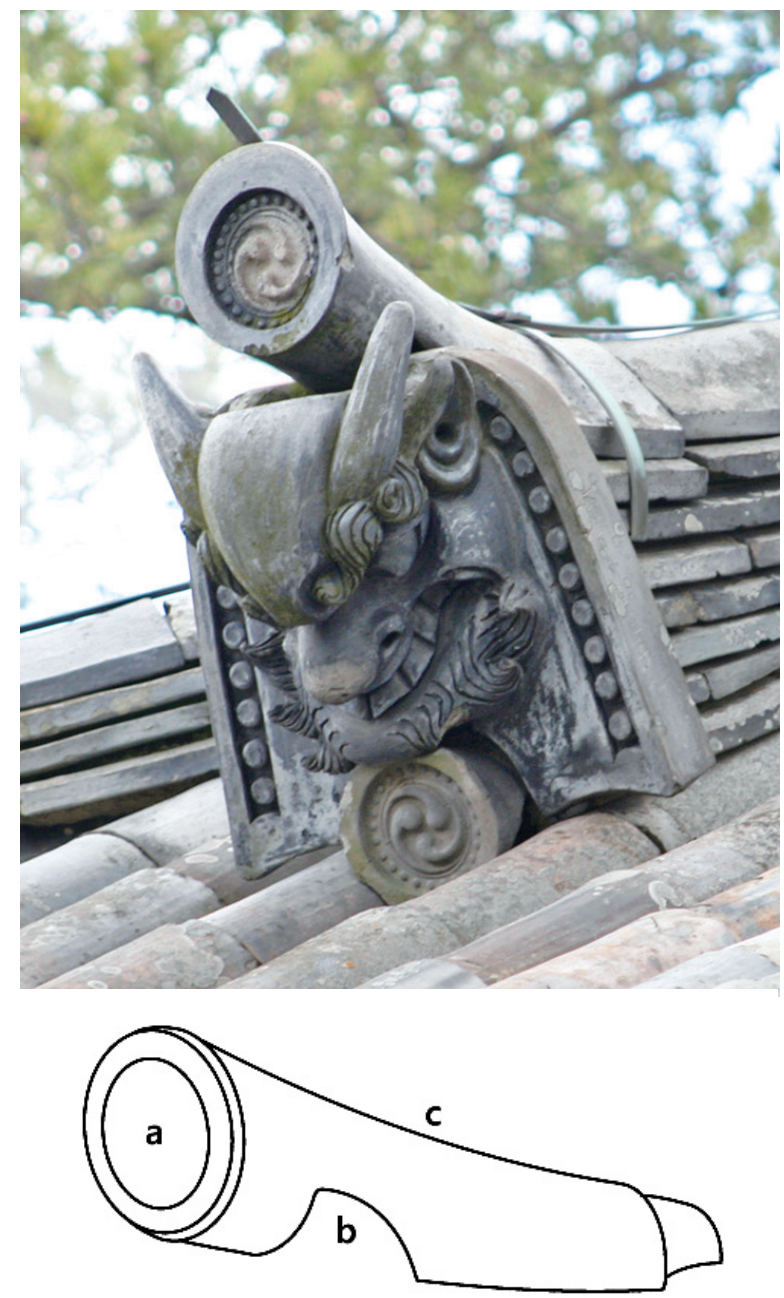
a) gatō 瓦当
b) ago 碩
c) sori 反り

Figure 7. Roof tiles and corresponding diagram. Great South Gate, Hōryūji, Nara Prefecture. Adapted from JAANUS online (toribusuma).

making tiles with a fairly standardized design, as in the motifs used for gatō mon'yō 瓦当文様 (circular antefixes to which patterns, motifs, and designs are applied), ${ }^{10}$ or a tile with a more planar design (as is the case with most other Japanese demon tiles from the same period), but it would be difficult to carve realistic forms like those

from an original carved mold." The author concurs with this view. [n8]

10 JAANUS online: see www.aisf.or.jp/ jaanus/deta/g/gatoumonyou.htm. 
of the Style I-A-richly pliable and inflected as they are-into wood, and to invert the concave and convex dimensions. The number of demon tiles required for construction, especially those of Style I-A, would have been insignificant compared to other types of roof tiles. Apart from an improvement in strength and durability, little justification can be found for wood being an essential component in making tiles. We may reference roughly contemporaneous clay molds for clay plaques, or senbutsu 塼仏, from Tachibanadera 橘寺 and Yamadadera 山田寺 in Nara, where clay is also the material for small, simple clay statues from these same temples. ${ }^{11}$ Clay molds have also been found on the Korean peninsula - for example, a demon tile mold from the Unified Silla period (Kr. T’ongil Silla shidae; Jp. Töitsushiragi jidai 統一新羅時代) (668-935) (figure 6). ${ }^{12}$ Given that tile-making technologies from the Korean peninsula influenced Japan, with the influence on northern Kyushu being especially notable, it is probable that clay molds were used for Style I-A. We will return to the relationship between Unified Silla period tiles and Dazaifu Style I tiles later in this article.

The shape of the Style I-A tile is a trapezoid, the top side of which swells into an arch and the bottom center of which utilized the cut-out of a half circle. A fleshy demon face is framed by a bordering row of low-relief hemispherical beads (shumon 珠文) set within two relatively fine raised lines, and another fine raised line at the outer edge. Twenty-four beads dot each side, with forty-eight in total. On the upper part of the tile, above the demon's forehead, we find a semicircle hollowed flat to accommodate a long cylindrical tile called a toribusuma 鳥食 that rests on top of it. ${ }^{13}$ At the glabella (between the eyes) is a hole that pierces through front to back, also likely related to the assembling of multiple tile types (figure 7). The downward-glaring pupil and iris of the ogre are represented as concentric circles on bulging eyes that threaten to pop from their sockets. Although the outlines of the iris and pupil appear to

11 The author observed the actual mold in the archaeological exhibition room of Tokyo National Museum's Heiseikan (hall). Also noted in Kuno and Mochimaru, Oshidashibutsu to senbutsu. [n9]

12 Kungnip Kyŏngju Pangmulgwan, Silla wajeon, pp. 402-403, introduces six demon tile molds from the United Silla period and explains that they are ceramic, made by taking a negative mold made of clay blended with sand based on a prototype and firing it. [n10]

13 See http://www.aisf.or.jp/ jaanus/ (toribusuma), the basis for figure 7 . be carved lines, they are in fact slightly stepped. The surface of the eyeball is set closer to the tile than the downcast iris and the pupil hangs lower than the iris. The nose is broad and high, the flared nostrils are rounded, and the tip of the nose seemingly tugged upward. The nostrils are not hollowed out but rather slightly convex. The full high cheeks carry a single diagonally oriented shallow engraved line, although what it represents is unclear. Turning to the gaping mouth, a pair of large fangs protrude from the upper jaw, each with an engraved single vertical striation at the center and modeled slightly outward toward the viewer's space. Between them are lined up six rectangular teeth. In place of the lower jaw is the cut semicircle, from the sides of which peep out small and slightly convex fangs. Represented on the sides of the demon's undulating lips are two deep wrinkles, while the hair, the thick outer tips of the eyebrows, and the beard are expressed with slender gathered convex lines that fringe and frame the demon's face. To the left and right of the gaping mouth are what appear to be a vertical lining up of three beads that are in fact beads enveloped by the scrolling tips of the demon's beard.

The ferocity of the tile's demon face is expressed through a combination of elements operating organically and synchronically such that we can understand the complexity of the demon face design by referring to this expression. This concept is extremely important for the study of Style I-A. Fury causes the eyebrows and eyes to slant upward and the mouth to open widely, forcing the cheekbones to swell. Wrinkles stretch from the corners of the eyes under the movement of the swollen cheekbones. The furrowing of the space between the brows causes a vertical wrinkle between the start of the eyebrow and the bridge of the nose that accompanies deep horizontal curved wrinkles formed in the space between the eyes, flared nostrils, and the turned-up nose tip. The fleshy forehead is pushed upward by the raised eyebrows, forming a bundle-like sequence of downward arching concentric circles, and the ridged and severe contours of the eyebrows and eyelids strain the facial expression. The upper half of the tile is composed of widening ripples that in design terms flow downward, owing to contours such as the semicircular flattened hollow at the top and the downward arc of the eyebrows and eyelids. The structure of the lower part, on the other hand, moves upward due to the visual thrust of the half circle cut out at the bottom and a mouth distorted in anger into an upside-down 


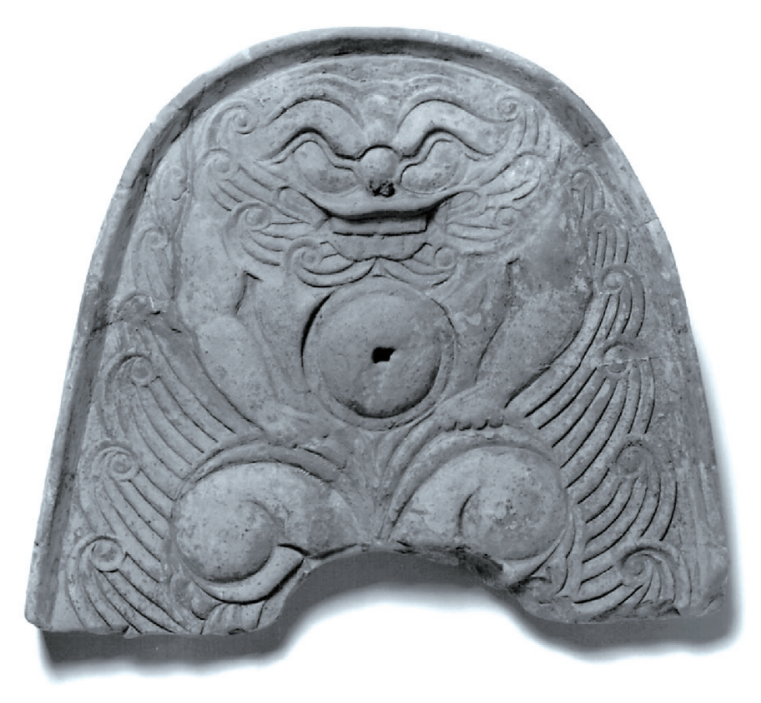

Figure 8. Roof tile, Heijō Palace Type Onigawara Style I-A. First quarter of 8th c., Nara period. Fired earthenware. $\mathrm{H} 39.5 \mathrm{~cm}$. Collection Nara National Research Institute for Cultural Properties.

U-shape. These upper and lower halves artfully converge at the tip of the nose. The way in which the direction of the gaze and the facial hair are represented also plays a role in perfecting the parts converging at the tip of the nose. This naturalistic, organically composed expression and accomplished modeling confirms that the concept and craftsmanship of Dazaifu Style I-A is a high point among demon tiles in Japan.

\section{The Formation of Style I-A}

The realistic, three-dimensional forms of Style I-A, with its organically linked parts, is unique among Nara-period demon tiles. Heijō Palace Type demon tiles (Heijō-kyū shiki onigawara 平城宮式鬼瓦), the cornerstone of eighth-century Nara-period onigawara (figures 8 and 9), have been divided roughly into six styles (Styles I-VI). ${ }^{14}$ Style II and onward, which show a complete demon face, began to be made after Dazaifu Style I-A demon tiles, during the second quarter of the eighth century or later. Style I, however, which shows

14 On Heijō Palace Type onigawara and the so-called Nara Great Seven Temples Type onigawara (Nanto shichidaiji shiki onigawara 南都七大寺式鬼瓦), I follow Morimitsu, "Nihon kodai no kimenmon onigawara," and also reference Iwato, "Nara jidai no kimenmon onigawara." [n11]

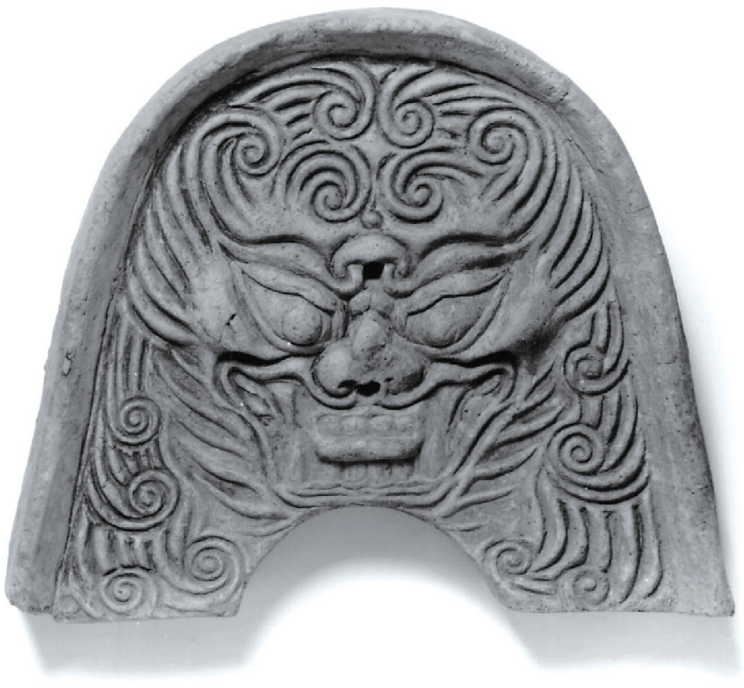

Figure 9. Roof tile, Heijō Palace Type Onigawara Style II-A. Second quarter of 8th c., Nara period. Fired earthenware. $\mathrm{H} 39.3 \mathrm{~cm}$. Collection Nara National Research Institute for Cultural Properties.

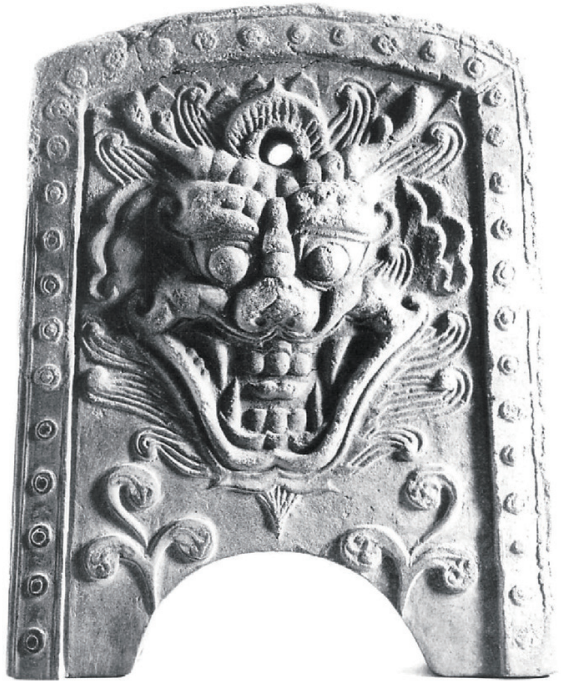

Figure 10. Mold for a demon tile. 7th-8th c., Unified Silla period. Fired earthenware. H $27.7 \mathrm{~cm}$. Collection Gyeongju National Museum. Reproduced from Kungnip Kyŏngju Pangmulgwan, Silla wajŏn, p. 330, no. 1080.

the whole body of the demon, was made during the first quarter of the eighth century, when Heijō-kyō 平 城京 was built. Heijō Palace tiles are important to consider alongside Dazaifu style tiles owing to their contemporaneous provenance and overall significance. 
That said, although some examples of Heijō Palace Type tiles have skillfully designed demon faces, most are designed to be flat, and the visual impact of their modeling is very different from the Dazaifu Type. The same can be said of the demon faces of onigawara from the so-called Seven Great Temples of Nara Type (Nanto shichidaiji shiki 南都七大寺式), which have been divided into six main categories and which began to be used in the state-sponsored temples of the Nara capital beginning with Tódaiji in the middle of the eighth century. The shape of both the Heijo Palace Type and Nanto shichidaiji Type tiles is a nearly half circle, and on this point as well they differ from the Dazaifu Type. It is hard to posit any direct link between these tiles of the capital and those from Dazaifu in terms of modeling and shape.

The standard view has long been to attribute the development of Dazaifu Type demon tiles to the influence from examples made on the Korean peninsula during the Unified Silla period (such as figure 10), and indeed the two share the same trapezoidal shape. Demon tiles from both places have beads along the peripheral edge and, despite differences in the composition and general tenor of the demon face, in both cases the facial features fill the tile save the borders; in a general way, we can regard the two as similar. Although the Unified Silla period demon tiles are smaller than the Dazaifu onigawara, among other notable differences, the influence of the peninsular works is indisputable and there can be no doubt that Unified Silla works are among the key sources for Dazaifu onigawara. As with the demon tiles from Dazaifu, other tiles from Kyushu are larger than the peninsular examples of the period, particularly those found at temple sites dating to the end of the seventh century in the northeastern area; a representative example is from the ruins of Tendaiji 天台寺 in Tagawa City 田川市, Fukuoka Prefecture. ${ }^{15}$ Tiles from the two places differ in that respect as well, but the discovery of eave-end tiles (nokigawara 軒瓦) ${ }^{16}$ with features charac-

15 The height of most demon roof tiles from United Silla is approximately $25 \mathrm{~cm}$ or less, as are round roof tiles and flat roof tiles. Roof tiles from Silla were used in Kyushu at the end of the seventh century. They are considerably smaller than Japanese roof tiles made in the Silla style, which clearly express Silla influence in their designs. This reflects differences between the two regions and their production and use of roof tiles. Kungnip Kyŏngju Pangmulgwan, Silla wajŏn, pp. 323-47. [n12]

16 Roof tiles placed along an eave line, including the semicircular nokimarugawara 軒丸瓦 (see http://www.aisf.or.jp/ jaanus/de-

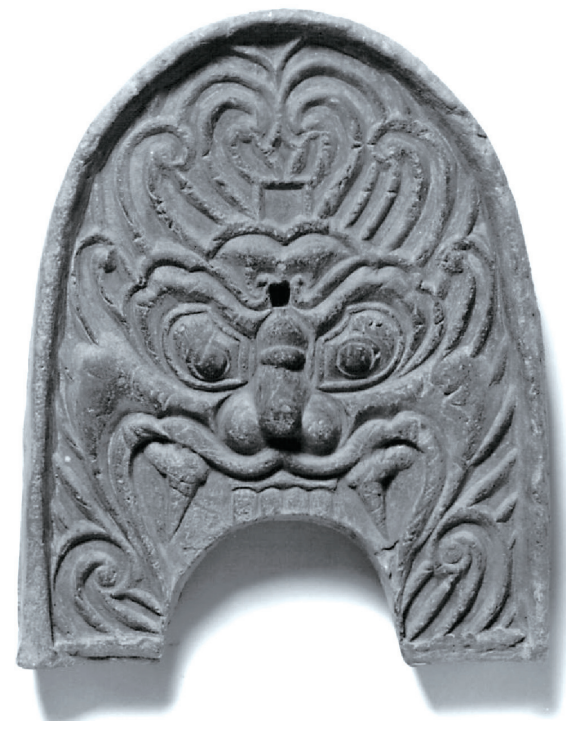

Figure 11. Roof tile, Heijō Palace Type Onigawara Style V-A. 8th c., Nara period. Fired earthenware. H $36.8 \mathrm{~cm}$. Collection Nara National Research Institute for Cultural Properties.

teristic of Unified Silla tiles - elaboration, delicacy, and a striking and lively demeanor - around northeastern Kyushu is worthy of note. ${ }^{17}$

That said, I have differed many times with descriptions that give the impression of a one-to-one influence between Unified Silla tiles and Dazaifu Style onigawara tiles simply because the tiles share such common elements as a trapezoidal outline, beading along the periphery, and a demon face that fills the entire surface. Even if we can posit a relationship between the two, to conclude that there is a one-to-one relationship between them is problematic. Such an approach fails to account for the different types of crafting and representational strategies for demon faces used for tiles from various sites around Nara-period Japan, and for those of the Unified Silla period, compared with those from Kyushu, as noted at the outset. The most striking features of the Dazaifu Type onigawara are the three-di-

ta/n/nokimarugawara.htm) and the bow-shaped broad concave pendant tiles nokihiragawara 軒平瓦 (see http://www.aisf.or.jp/ jaanus/deta/n/nokihiragawara.htm) are usually covered with a decorative design. They protect the ends of the eaves from rainwater and dampness.

17 On the so-called Silla lineage or Silla-style (Shiragi kei 新羅系) eave-end tiles in Kyushu, see Oda, "Buzen ni okeru Shiragi-kei kawara to sono igi," and Kameda, Nikkan kodai kawara no kenkyū, pp. 353-422. [n13] 


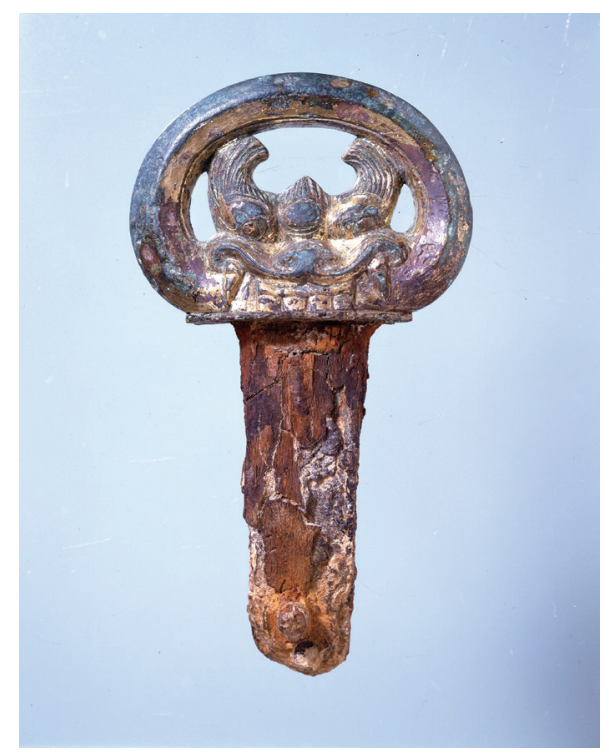

Figure 12. Ring pommel of a sword, shigami (biting lion) type. 6th c., Kofun (Asuka) period. Bronze. W $5.5 \mathrm{~cm}$. Excavated from Kanzaki burial mound 1, Fukuoka Prefecture. Collection Fukuoka Prefecture Board of Education.

mensionality of the demon face, high standard of craftsmanship, and skillful design. Ultimately, we cannot attribute the source for this paradigmatic demon face to the observation of works from the Unified Silla period.

To determine a possible source for the representation of a demon on Dazaifu onigawara, we point to a similar design on the Heijō Palace Style V-A (figure 11). Comparing the two frontally, we see some common elements: raised eyes in the shape of a fava bean, round pupils, a nose with flared nostrils and horizontal transverse wrinkles at their base, an upside-down U-shaped mouth, a rectangular row of teeth between fangs, and a fringe of facial hair blowing upward. As has been mentioned, the Dazaifu onigawara style emerged while the construction of the second phase of the government office was taking place during the second quarter of the eighth century. On the other hand, the Heijo Palace demon tiles were used exclusively after the second half of the eighth century. Given this time difference and considering the planar Heijo Palace Type Style V-A, with its more developed design, we should not offer a facile connection between the Dazaifu and Heijō Palace styles. The common features of these onigawara, however, do prompt us to ponder a Japanese source for the design of both types of demon face.

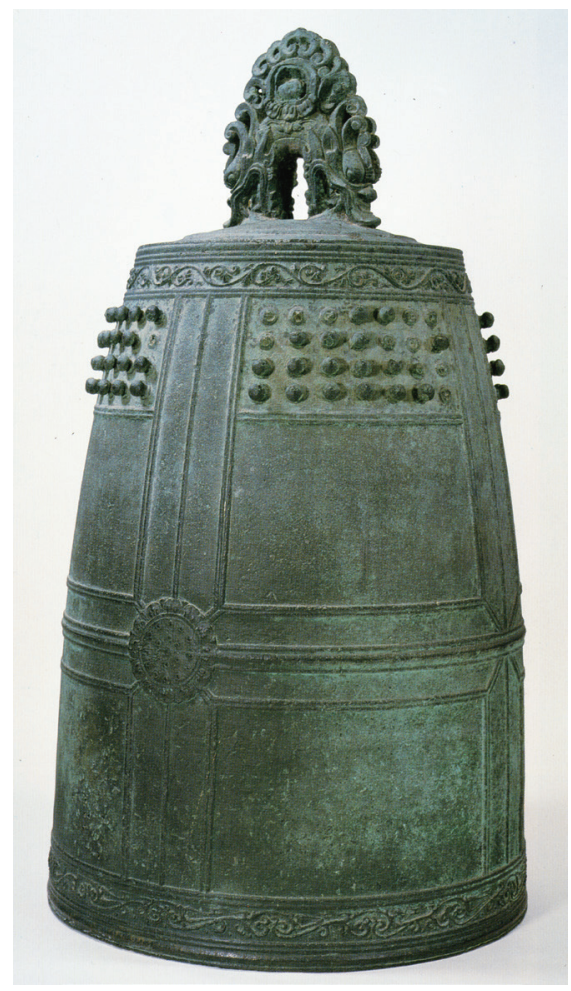

Figure 13. Bell (bonshō). Late 7th c., Asuka period. Bronze. H 159.9 $\mathrm{cm}$. Kanzeonji, Dazaifu, Fukuoka Prefecture.

If we look beyond onigawara at other artifacts we find further support for the idea of a Japanese source. A good example is the beast face (jūmen 獣面) seen within the sword ring pommel of a shigami (literally, "biting/gnawing lion," Shigamikantō tsukagashira 獅 噛環頭柄頭), excavated from Kanzaki 神崎 burial mound (figure 12). Although much smaller and more elaborately designed, there are similarities between this beast's face and that of the Dazaifu Type demon tile. These include eyebrows that seem to burst into flames, slanted eyes, round pupils, a nose with flared nostrils that have a horizontal crease at the sides, and squared teeth between two long fangs. Despite its purported sixth-century provenance, its fierce demeanor seems to be even closer to the Dazifu Type Onigawara than to the Heijō Palace Type Onigawara tile Style V-A. Pursuing this, it becomes possible to presume a relationship between Dazaifu Style I-A and a preceding demon or beast face in Japan, if not Kyushu. Subsequentlyafter the sword pommel and continuing into the Nara period-we can observe in Kyushu the pattern of a beast with a high-level of design and modeling, as 


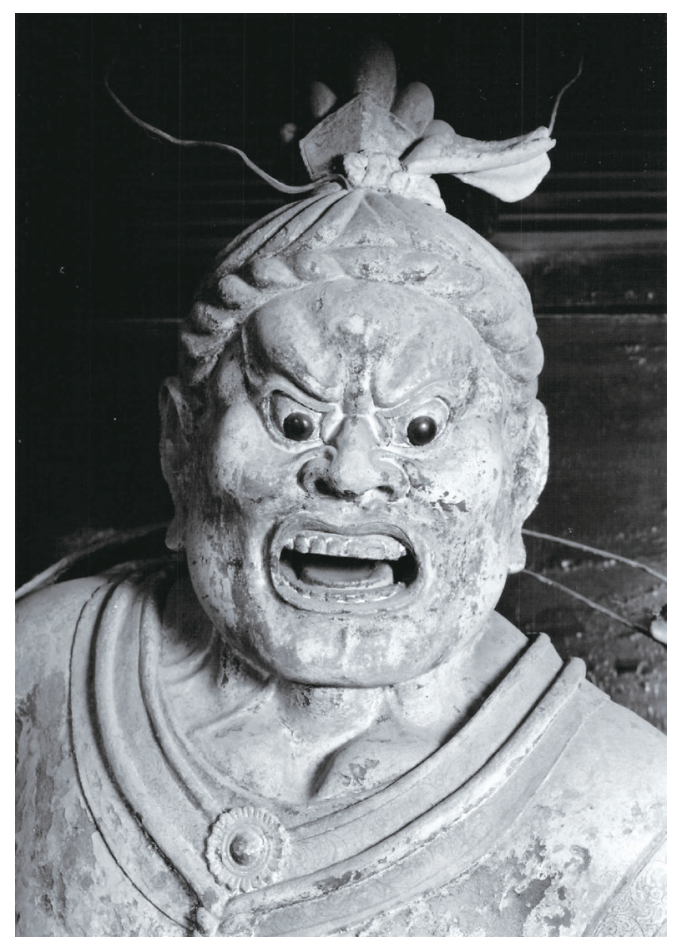

Figure 14. Statue of Shūkongōjin, detail. Mid 8th c., Nara period. Clay with polychrome and gold. H $173.9 \mathrm{~cm}$. Hokkedō, Tōdaiji, Nara Prefecture.

seen in a dragon head on the top of the late seventhcentury temple bell at Kanzeonji 観世音寺 (figure 13). ${ }^{18}$

We can consider the formation of the Dazaifu Type Onigawara as situated at the intersection of demon tiles of the Unified Silla period and the flow of the formation of the beast face and demon face. Yet merely placing a Japanese demon face on the outline of a demon tile from the Unified Silla period does not make a Dazaifu style onigawara. Various other elements beyond outline and face converged to form this new creation. A key characteristic of the Dazaifu Type is a demon face that seems to jump out of the frame, with its natural expression and organically linked movement of bone and muscle. This could be realized only through the

18 The bell at Kanzeonji is in keeping with the style of Japanese bells, yet the influence of styles from the Unified Silla period can be discerned in the design of the upper band and the lotus pattern on the tsukiza 撞座 (the part hit by the hammer). See Igata, "Kanzeonji no bonshō," which discusses previous scholarship. This bell is important not only as a precedent for the representation of a beast, but also as a work that responds to outside trends created before the Dazaifu tiles under discussion. [n14] efforts of craftsmen capable of configuring an advanced design and finishing it in high relief, with the ability to craft skillfully with speed or deliberation and in deep and shallow relief. My assertion is that the craftsmen who created the prototype for the mold, which is thought to have been made of clay, were likely makers of Buddhist images, who were specialized in making complicated three-dimensional works with handbuilt (nenso 捻塑的) techniques. ${ }^{19}$ The special characteristic of eighth-century sculptural works in clay such as the Shūkongōjin 執金剛神 of Tōdaiji's Hokkedō 東 大寺法華堂 (figure 14) is the combination of more naturalistic forms and facial expressions, using mainly handbuilt techniques, with the representation of more natural textures and surfaces. Looking at the faces of the Nara works, we see that the artist was certainly conscious of the movements of bone and muscle, the organic coordination of which enables the expression of an intended emotion. This naturalism and sense of unity in the modeling and composition of the face is not seen on all Nara-period demon tiles, with their strong linear design sense and planar presentation, while it is striking in Dazaifu Type demon tiles.

Surely the artisans of Buddhist objects and statues played leading roles in the technical aspects for and conceptualization of the face on the Dazaifu Style demon tiles. Clay statues were made for many temples, like Kanzeonji, that were under Dazaifu's jurisdiction at that time. Beyond appearing in historical documents, ${ }^{20}$ the existence of such statues is clearly proven by fragments that have survived at Kanzeonji (figures 15 and

19 Such a view is championed by Yahiro Izumi, who offered many insights that inform the present author's perspective. [n15]

20 A representative example is a group of clay statues of the Four Guardian Kings (Shitennō 四天王) made for Shiōji, Shiōin 四 王寺·四王院 (i.e., Shitennōji 四天王寺), six shaku tall, in Hōki 宝 亀 5 (774). These statues were created to combat maledictions from the Korean peninsula (Silla). See a document issued by the Grand Council of State (Dajōkanpu, Daijōkanpu 大政官符),「応奉 造四天王寺埝像四躯事」, dated 774.3.3 in Ruijū sandaikyaku (Ruijū sandaikyaku, zenhen, Shintei zōho kokushi taikei, p. 45). Further, most of the statues listed in a 905 document from Kanzeonji seem to have been crafted of clay. See: "Engi gonen Kanzeonji shizaichō" (Tokyo University of the Arts collection), reproduced in Dazaifushi shi henshū iinkai, Dazaifushi shi kodai shiryōhen, pp. 705-70. Yahiro discusses these examples in Dazaifushi sh henshū iinkai, Dazaifushi shi kenchiku bijutsu kōgei shiryōhen, pp. 579-88. See also several short studies by Igata, including "Shiōji to Shitennōzō o tazunete" and "Seichi Dazaifu no hotoke tachi." [n16] 


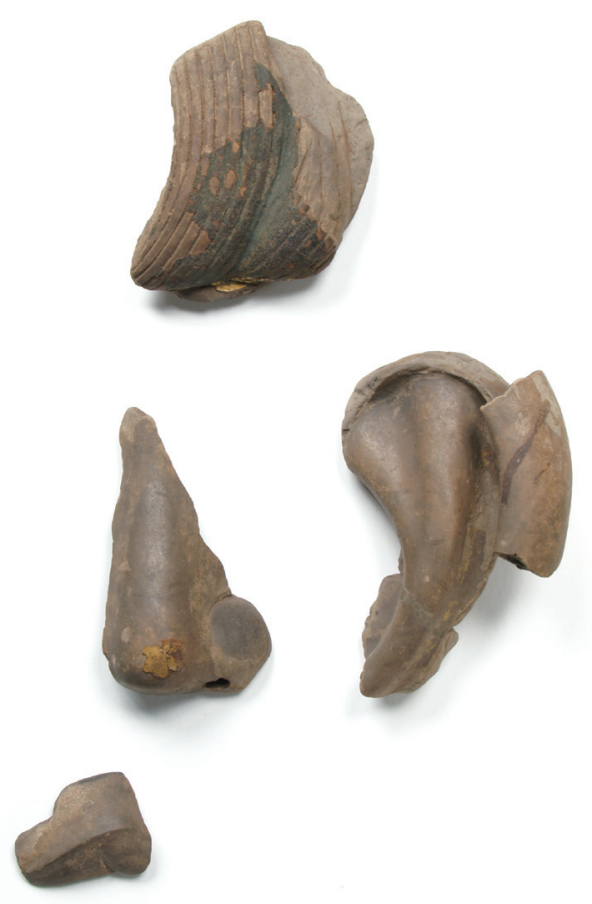

Figure 15. Fragments of a Fukūkenjaku Kannon statue. 8th c., Nara period. Clay with traces of lacquer and polychrome on the surface. Kanzeonji, Dazaifu, Fukuoka Prefecture.

16). ${ }^{21}$ We can say that the circumstances that allowed for the foregoing idea to materialize, a proposition guided by the mode of representation and the execution (modeling) of the onigawara roof tiles, were well established: the Dazaifu Type demon tile was a new representational model created in the Nara period at Dazaifu that was accompanied by techniques of craft not found in other tile types, one that referenced various earlier models yet clearly differed from them.

It is also possible that Dazaifu onigawara from that time were conceived with an awareness of tiles not only from works made during the Unified Silla period but also during the Tang dynasty (618-907). Dramatic developments at Dazaifu in the eighth century are linked to major shifts in governance from a system modeled on Korea in the seventh century to one

21 On the fragments of clay statues at Kanzeonji, see Dazaifushi shi henshū iinkai, Dazaifushi shi kenchiku bijutsu kōgei shiryōhen; Kyūshū Rekishi Shiryōkan, Kanzeonji: Ibutsuhen; and Kyūshū Rekishi Shiryōkan, Fukuoka no shinbutsu no sekai: Kyūshū hokubu ni hana hiraita shinkō to zōkei. [n17]

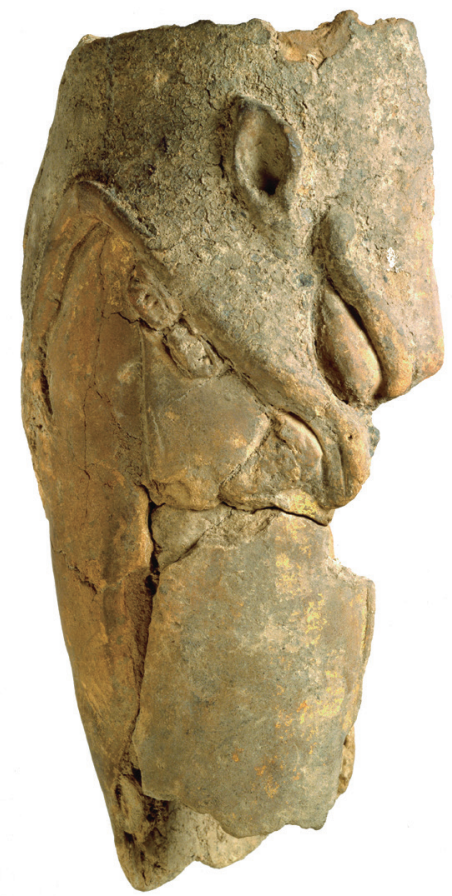

Figure 16. Fragment of the arm of a protective divinity, likely a Shitennō. 8th c., Nara period. Clay with traces of lacquer and polychrome on the surface. Kanzeonji, Dazaifu, Fukuoka Prefecture.

modeled on Tang China entering the eighth century. ${ }^{22}$ Both tangible and intangible cultural elements were oriented toward Tang China, important examples being the Taihō Code and the creation of the Nara capital. In such circumstances, we should acknowledge that those in Dazaifu may have been aware of the Tang dynasty system of using demon-face tiles on the outer edges of roofs, a possibility that was reflected in the features of the richly three-dimensional demon face. ${ }^{23}$

As noted above, in terms of overall shape, Dazaifu Type onigawara are similar to demon tiles from the Korean peninsula during the Unified Silla period. Because Dazaifu tiles are clearly crafted differently from

\footnotetext{
22 Kanegae, Zenshū Nihon no rekishi 3, pp. 79-91; and Kanegae, "'Nihon no nanaseiki shisaikō: Kenzuishi kara Taihō ritsuryō made," pp. 73-75. [n18]

23 Morimitsu points to the modeling of the ritsuryō system based on the influence of Tang precedents and the possible influence of Tang models on the design of the tiles. Morimitsu, "Nihon kodai no kimenmon onigawara," pp. 59-61. Following Morimitsu's lead, this study also considers possible Tang dynasty influence on the modeling and style of Dazaifu onigawara. [n19]
} 
Silla tiles, however, it is possible that we should be looking toward Tang China for connections in this regard. However, though onigawara featuring a demon-face design and rich three-dimensionality can be found among Tang-dynasty demon tiles, no known example seems to be a direct predecessor of the Dazaifu types. Even if there had been an attempt to imitate Tang-dynasty demon tiles, in the absence of craftsmen with precise knowledge of the styles and modeling techniques a faithful imitation would not have been possible. We can hypothesize in such a case that imaginative imitations or replicas would have been made based on demon tiles from Silla or some other reference material. ${ }^{24}$ The circumstances for the systemic adoption of the demon face on the tile (as opposed to other types of presentations, such as the whole or partial body of the ogre) cannot be the same as those underlying the establishment of specific representational models. We should take care not to conflate the two processes.

This is to say that the particular modeling and manner of expression used for the ogre face on the Dazaifu Type onigawara finds no parallels. Demon roof tiles originally functioned both as tiles that protected against weather elements and as striking ornamentation of the roof edges; tiles with a demon face also functioned, in a general sense, to ward off evil. Although these roles are important to bear in mind when considering Dazaifu Style demon tiles, if the tiles functioned merely as a kind of device, ornament, or talisman, there would be little motivation to develop a new mode of three-dimensional and realistic modelling with its many concomitant technical challenges to effectively carry out the representational schema. At the time this new mode was developed, however, a need certainly did exist. We can think of that need as intimately connected to the character of the location, which in this case pivots around Dazaifu during the second construction phase of the Dazaifu Government Office, for which preparations were underway in the first quarter of the

24 Although different in terms of both time and place, Western-style architecture in the Meiji period (1868-1912) can serve as a helpful reference. At the dawn of the Meiji period, Japanese carpenters sought to construct Western architecture but lacked a clear understanding of it, so they ended up building Western-style structures based on the information that was available and the skills they had mastered. The intention was to create Western architecture, but what was built was architecture unique to Japan during the Meiji period. I believe a similar situation exists in the case at hand. [n2o] eighth century. Here, then, I would like to consider the function of the Dazaifu Type demon tile from another angle, in terms of its context-its relationship and interconnectedness with the role of Dazaifu. ${ }^{25}$

During the eighth century, Dazaifu developed into a center of diplomacy and regional control, along with its continued function as a military base. Addressing the deployment of Dazaifu Style I-A demon tiles at administrative facilities, we know that they were principally used at the Dazaifu Government Office area and environs. There was Ōno Castle on the hilltop to the rear of the government office area, an area called Jōbōiki 条坊域 to its front, and beyond Jōbōiki, atop another hill, Kii Castle (Kiijō 基肄城). The site felt like Heijō Palace (Heijō-kyū 平城宮) on a reduced scale. Impressive structures, built in a uniform style called the Chōdō'in style (Chōdō'in yōshiki 朝堂院様式) and aligned in an orderly fashion, the Daizaifu Government Office would have manifested the grandeur of the place. These types of buildings fulfilled more than purely practical functions. We can think of them as dual purpose: enabling the execution of administrative affairs and formal ceremonies and at the same time serving as symbols of Dazaifu's power and character. We can surely see the onigawara, the roof tile, as critical for the embellishment of these buildings, performing a function of symbolic significance. The demon faces of the onigawara would have projected a refined power through the chiaroscuro effects produced by sunlight, making a strong impression on those who visited Dazaifu. The demon tiles are an aggregate of all that Dazaifu exemplified or what it sought to exemplify. Demon tiles were crafted to elicit an instinctive response and perhaps "authority and strength" (ibu 威武) would be the most apt characterization of their message. The term $i b u$, to give one example, is found near the beginning of an imperial decree dated Hōki 宝亀 11 (780).7.26 in the 797 Shoku Nihongi 続日本紀. It notes that Dazaifu in Tsukushi 筑紫 on the distant Saikai[dō] 西海 is dependent on tribute and supplies from many provinces sent by boat such that trained and experienced warriors and horses of the best quality should be dispatched to reinforce its authority and strength and to equip it in extreme circumstances.

\footnotetext{
25 For a survey of Dazaifu based on current understanding in the academic literature, see Sugihara, Tō no mikado. This study draws primarily on Sugihara for its overview of Dazaifu. [n21]
} 
Six articles of defense (Kegorokujō 警固六条) are given for the several provinces fronting the sea along the Hokurikudō 北陸道 to alert them to prepare for possible threat from the Korean peninsula. ${ }^{26}$

\section{Kimen: The Demon Face}

The "demon face" (kimen 鬼面) of the Dazaifu style demon tiles is generally called just that, a demon face, but what that means exactly has escaped attention. Only one study by Oda Fujio, to my knowledge, makes an effort to interpret the meaning of kimen:

[The Japanese tile] kimen derive directly from Unified Silla period demon tiles with beast face designs (獣面文鬼板瓦), but their origin can be traced to the Chinese qitou "ghost heads" (Jp. kitō 䰠頭), tomb guardian beasts (Ch. zhenmushou, Jp. chinboju 鎮墓獣) of the Sui (581-618) and Tang dynasties. The original meaning of "ghost heads" derives from the idea of warding off evil, such that we might imagine that the Japanese demon-face design holds the same meaning. The creativity of culture in Dazaifu should not go unnoticed: their demon face tiles express sublime ferocity and rage, do away with the legs of the beast seen on Silla demon tiles, and incorporate many facial elements similar to humans. ${ }^{27}$

These words were written more than half a century ago, yet they still offer crucial insights into the study of Dazaifu Type Onigawara, including several key aspects of the present examination. I would therefore like to consider the demon face depicted on Dazaifu Type Onigawara in the manner suggested above.

The demon face is humanlike but not human, beastlike but not that of a beast. Some aspects of the shape of its eyes, nose, and so forth relate to the fierce expressions of Buddhist images, but other elements dif-

\footnotetext{
26 Takeuchi, Dazaifu, Dazaifu Tenmangū shiryō, pp. 216-18. [n22] See also Ruijū sandaikyaku, kōhen, p. 547 (Shintei zōho kokushi taikei, vol. 2-7). 「(七八○) 七月戊子《廿六》戊子。勅曰。筑紫大宰僻居西海。 諸蕃朝貢舟楫相望。由是簡練士馬。精鋭甲兵。以示威武。以備非常。今 北陸道亦供蕃客。所有軍兵未曾教習。属事徵發。全無堪用。安必思危。 豈合如此。宜准大宰依式警盧。事須縁海村邑見賊來過者。當即差使速 申於國。國知賊船者。長官以下急向國衙。應事集議。令管内警盧且行 且奏。000」. With Ross Bender.

27 Oda, Shiragi no kogasen, p. 47. [n23]
}

fer, such as the large mouth, fangs, and body hair. This unusual demon form also differs from demon tiles of the Unified Silla period, which were once regarded as direct sources for the Dazaifu tiles and which are widely believed to have influenced the general shape of the Daizaifu onigawara. Although we cannot simply lump together all demon tiles from the Unified Silla period, generally speaking their demon faces have angry eyes, fangs, wavy hair, and on many appear a pair of horns that resemble deer antlers. Their appearance does not bring to mind humans or Buddhist images but rather a sort of sacred beast. Some tiles show forelegs beneath the demon face, legs similar to those of four-legged animals. In terms not only of design and modeling but also of the emotions expressed, the demon face of Dazaifu Style I-A onigawara differs from that of Unified Silla period tiles. Although demon tiles from Silla have been described as having a demon-face design and beastface design, Kang Ubang has proposed that they depict dragon faces ${ }^{28}$ Judging from the shape of the tile, I find his theory rather convincing. In this conception, the ridge lying on the roof forms the body of the dragon. Kang points out that the major motivations for creating these tiles are protection against fire and, of course, protection against evil. Surely, the Dazaifu Type onigawara and those from the Unified Silla period differ in both the design of the demon face and its function. As argued above, it is difficult to posit a direct one-to-one connection between the two.

The Dazaifu Type demon tile is generally regarded as the first example of a demon-face design to be adopted for use as a roof-edge tile in Japan. ${ }^{29}$ Even so, that is not necessarily indicative of Dazaifu's innovation. Consider here that the decision to adopt the demon face was issued from the center. Dazaifu was originally a branch office of central government, and we know from historical sources that onigawara with a demon-face design spread throughout Japan on the heels of their production in Dazaifu. It would be overly simplistic to think of the flow as proceeding from Dazaifu to the

\footnotetext{
28 Kang, "Han'gug wadang yesullon sŏsŏl," pp. 424-28. [n24]

29 Morimitsu notes that demon-face onigawara may have existed as far back as the seventh century, based on materials excavated from the Koyagi 小八木 temple ruins in Shiga 滋賀 Prefecture and the Senbon 千本 ruins in Hyogo. The location of these materials (relative to the whole) is not entirely clear, however, and each are isolated examples, so I feel it is inappropriate to regard them as the first examples. Morimitsu, "Nihon kodai no kimenmon
} onigawara," pp. 58-59. [n25] 
Nara capital, and subsequently to the whole country, I think that around the time Dazaifu Type Onigawara production began, a decision was made in the capital to use a demon face on the roof-edge tiles of government buildings to ward off evil; the first time they were made was when work began on the second construction phase of the Dazaifu Government Office in the first quarter of the eighth century. If this is the case, we should reference Heijo Palace Type Onigawara-not those from the Unified Silla period - to better understand the meaning of the demon face on tiles. We can think of both Dazaifu and Heijō Palace onigawara as having in common a "demon." Among the Heijō Palace Type Onigawara, it is significant that Styles II and later, which show a large demon face, were likely created after Dazaifu Type Onigawara Style I roof tiles began to be made, but Heijō Palace Type Onigawara Style I tile production began prior to that of Dazaifu Style I. More specifically, however, Heijo Palace Type Onigawara Style I-A is the first tile in Japan to use the form of a demon, but not a demon face. The shift from an auspicious pattern applied to roof tiles, such as the prevalent lotus flowers, especially at temples, to a demon shape occurred at this point, after which came tiles with a demon face filling the entire surface. In short, even though the Heijo Palace Type Onigawara Style I-A and Style II-A tiles look different, the faces of the two can be similarly described and it is possible that the two styles are consecutive. In short, we should take close note of the Heijō Palace Type Onigawara Style I-A, which precedes the Dazaifu Type Onigawara Style I-A.

Chinese dragons described as taotie (Jp. tōtetsu 饕 䬸), local divinities (shenxiang 神像), "ghost heads," lions (shiji 獅子), and more creatures have been proposed as possible sources for the Japanese onigawara demon face..$^{30}$ Here I reconsider the demon representation on Heijō Palace Type Onigawara Style I-A with

30 Yamamoto, in "Shitadashi jūmen kō," introduces previous studies that posit various origin theories, including the taotie pattern on bronzeware of the Yin and Zhou dynasties, images of deities from the Six Dynasties period, and qitou of the Sui and Tang dynasties. After introducing these studies, Yamamoto makes the novel proposition that shishi (lions) constitute the origin. Morimitsu supports the theory introduced in Kobayashi, "Onigawara kō," which views deity statues as the origin. Morimitsu considers the demon-face design in terms of gods from ancient China who invite good luck and ward off evil. This essay follows Morimitsu's theory based on design analysis and advances it using a discussion of Dazaifu Type demon tiles. [n26] these points in mind. Referring to figure 8 , the demon wears nothing but knee-length shorts and crouches with knees bent and hands clenched in fists on the thighs. Its large eyes slant upward, and the corners of the mouth are upturned. The tongue hangs out, with upper teeth and fangs exposed, and a long, curly beard fringes the face. Aura or cloud-like forms fill the space that surrounds the demon's body. The body is muscular but not excessively so; there is also an intensity to the face, with its angry expression, yet it imparts an almost light-hearted and humorous feeling with its protruding tongue and oversized head reminiscent of a child ( $d \bar{o} j i$ 童子). Surveying East Asia, what comes to mind as something that functions to ward off evil and has these kinds of characteristics are the various spirits or demonic gods called guishen (Jp. kishin 鬼神), generally referred to as monsters, or weishou (Jp. iju 畏獸), that first appeared in the Han dynasty in connection with tombs but later flourished in Buddhist imagery. ${ }^{31}$ An excellent example relatively proximate in time and one cited in previous studies is a demonic winged kneeling creature of composite animal form in relief from the mountainside limestone Chinese caves of Xiangtangshan 北響堂山石窟 in the village of Hecun 和村, Hebei Province 河北省 (figure 17), dating to the early part of the Northern Qi dynasty (550-577). In the cave, the kneeling creatures hold up elaborately decorated columns..$^{32}$ Due to differences in period and place, representation of the beast differs and the figure has wings on the shoulders, which also differs, but generally it also has many features in common with the demon figures of the Heijo Palace tiles Style I-A. Such Chinese weishou or monsters that functioned to ward off evil are thought to be the source for the demon face of Japan's onigawara. Weishou first appeared in China in connection with tombs but eventually their use spread to Buddhist monasteries, with their very different philosophical basis, wherein their representation diversified. Of great interest here is that this evolution is similar to that of the demon-face onigawara in Japan, which first appeared in palaces but then was deployed in Buddhist temples. Despite the single term weishou for the monsters, their great variety of types and forms means that a

31 On Chinese monsters, I draw primarily from Hayashi, "Kanda kishin no sekai"; Azuma, "Hokuchō, Zui Tō to Kōkuri"; and Tamura, "ljū-zō shōkō." [n27]

32 Tsiang, et al., Echoes of the Past: The Buddhist Cave Temples of Xiangtangshan, p. 159. 


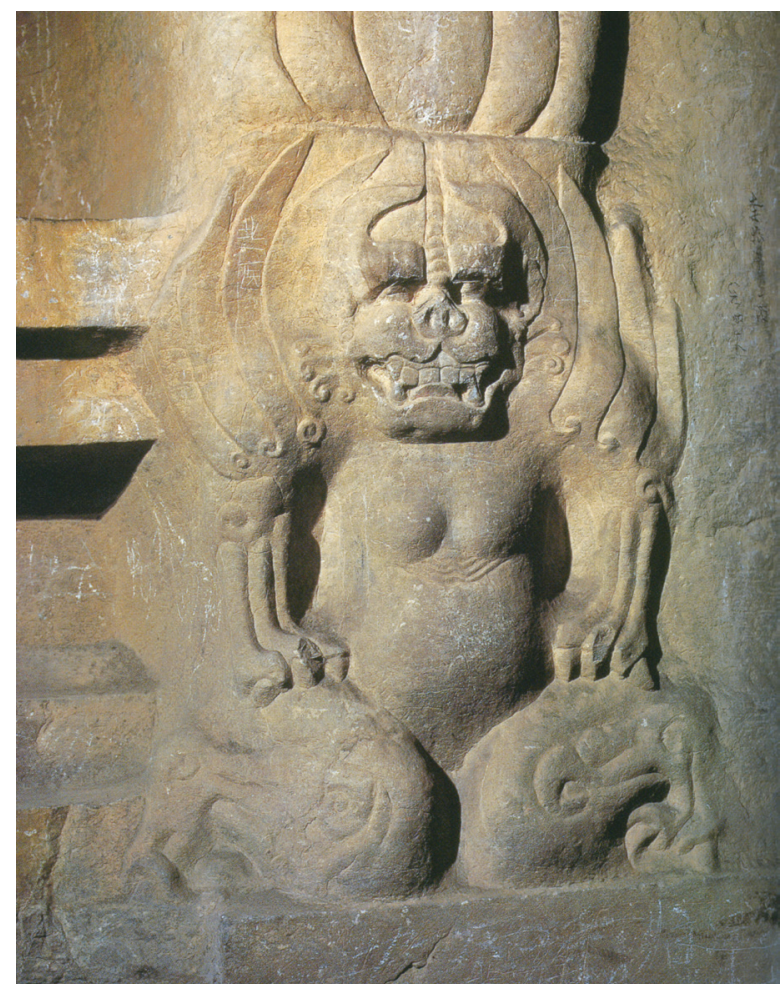

Figure 17. Kneeling winged monster in relief from Xiangtangshan Buddhist caves. Ca. second half of 6th c., Northern Qi dynasty. Limestone. North Cave, Northern group of caves, Hebei Province. Reproduced from Shōgakukan, Sekai bijutsu zenshū, p. 246.

proper definition is impossible. At some point, weishou were probably understood in the big picture as a spirit or demonic god to ward off evil, although even if there had been a rigorous distinction among definitions it was lost at some point in time. There is no doubt, however, that at least by the time demon-face onigawara appeared in Japan there was certainly an awareness of the existence of Chinese monsters.

Returning to the Dazaifu Style demon tile, it is an example of an early demon-face onigawara, it is humanlike but not human, beastlike but not a beast, and like a wrathful Buddhist image but different from Buddhist images. Ultimately the onigawara demon face is a creature that functions to ward off evil, and we can assume that the tile was specifically designed to emphasize the demon face. Note, however, that the face of the Dazaifu Style I-A demon does not show a tongue owing to the semicircular cutout in the bottom middle section and also lacks the sense of whimsical humor present in representations of the Chinese weishou, but these same features are seen in the Heijō Palace Style I-A and the subsequent II-A demon depictions.

Sculptural works of the Nara period, including Buddhist clay statues, elicit a sense of awe through their classically chiseled beauty. Dazaifu Type Onigawara share these characteristics because, I believe, it was Buddhist craftsmen who made the prototype for Dazaifu Type Onigawara. In this way they differ from both Heijo Palace Type demon tiles and the monsters of China that protected against evil, despite appearing at the same time as the former and continuing the lineage of an evil monster of the latter. The Dazaifu tiles were created as representations full of refinement and intensity. We can suggest that what brought about these features is the character of Dazaifu itself. From the time it was established in the seventh century, Dazaifu was of exceptional military significance within Kyushu and within East Asia. In the eighth century Dazaifu continued this role while coming into its own. Dazaifu and the onigawara produced in Dazaifu served as symbols of "authority and force" in East Asia and Kyushu.

\section{Conclusion}

Dazaifu Type Onigawara Style I-A emerged as a new type of tile during the first quarter of the eighth century, which coincides with the second phase of the construction of the Dazaifu Government Office. It offers an amalgamation of ideas and modes of representation seen in Unified Silla period demon tiles from the Korean peninsula, the representation of beast faces in Japan, and Chinese monsters. The superb skills in handbuilt techniques of the Buddhist artisans who crafted the Dazaifu onigawara underpins their most distinguishing characteristic: each part of the demon tile is organically coordinated to form an imposing wrathful countenance through a sense of dimensionality and the use of refined modeling. Tiles like these from the eighth century are not found elsewhere in Japan. We are tempted to describe the style as "Dazaifuesque," echoing a phrase used in the early ninth century to describe Dazaifu as "neither capital nor province but somewhere in between” (非京非国、中間孤居), that is, neither center nor periphery. ${ }^{33}$ High-relief surfaces

33 From a document issued by the Grand Council of State on Jōwa 承和 5 (838).6.21. See Ruijū sandaikyaku, kōhen, p. 333 (Shintei 
became an increasingly common feature of onigawara when their main function became less about warding off evil than of dramatically presenting the stateliness of buildings while demonstrating the integrity of the tile. Considering differences of both period and location for production, however, it is difficult to claim that Dazaifu Type demon tiles were the direct source for subsequent onigawara. Dazaifu tiles did foreshadow later developments, yet at the same time they are unique through all times and places.

Dazaifu Type demon tiles exerted an influence on the entire Kyushu region, but only during the eighth century of the Nara period, when Dazaifu ruled Kyushu through the great power of the ritsuryo state. The unique nature of the tiles is underscored by the fact that no works that continue the style during the Heian era have been found in Kyushu or elsewhere. This notion of uniqueness may be inappropriate beyond the confines of onigawara: "Kyushu" is frequently mentioned as if it formed a self-evident framework, but no other examples readily come to mind in the design of new forms created or developed within the confines of Kyushu itself. This necessitates caution when using such a framework.

The same critical elements that shaped the development of Dazaifu Type Onigawara are also key to the history and culture of Kyushu: influence from the Nara capital, influence from the continent, and local traditions. Symbols of Dazaifu's ibu (authority and power) in the past, and still symbols of Dazaifu's historical sites, Dazaifu's demon tiles are important cultural remains for the study of Kyushu's history and culture.

\section{Reference List}

Azuma Ushio 東潮. “Hokuchō, Zui Tō to Kōkuri hekiga shishin zuzō to ijū zuzō o chūshin to shite” 北朝·隋 唐と高句麗壁画 四神図像と畏獣図像を中心として. Kokuritsu Rekishi Minzoku Hakubutsukan kenkyū hōkoku 国立歴史民俗博物館研究報告 8o (1999), pp. 261-325.

Dazaifushi shi henshū iinkai 太宰府市史編集委員会, ed. Dazaifushi shi kenchiku bijutsu kōgei shiryōhen 太宰府市 史建築美術工芸資料編. Dazaifushi, 1998.
Dazaifushi shi henshū iinkai 太宰府市史編集委員会, ed. Dazaifushi shi kodai shiryōhen 太宰府市史古代資料編. Dazaifushi, 2003.

Hayashi Minao 林已奈夫. “Kandai kishin no sekai” 漢代鬼 神の世界. Tōhō gakuhō 東方学報 46 (1974), pp. 223-306. Igata Susumu 井形進. “Dazaifu-shiki onigawara kō: I-shiki A o chūshin ni” 大宰府式鬼瓦考: I 式Aを中心に一. In Dazaifu shiseki hakkutsu 50 shūnen kinen ronbunshū $k a n k o ̄ k a i$ 大宰府史跡発掘50周年記念論文集刊行会, ed. Dazaifu no kenkyū 大宰府の研究, pp. 561-74. Koshi Shoin, 2018.

Igata Susumu. "Dazaifu-shiki onigawara: I-shiki A no zōkei to sono seiritsu no yōsō o chūshin ni” 大宰府式鬼瓦: I 式Aの造形とその成立の様相を中心に. Kōkogaku jānaru 考古学ジャーナル 588 (2009), pp. 28-32.

Igata Susumu. “Dazaifu-shiki onigawara shōkō” 大宰府式 鬼瓦小考. Kyūshū Rekishi Shiryōkan kenkyūronshū 九州 歴史資料館研究論集 28 (2003), pp. 1-30.

Igata Susumu. "Dazaifu-shiki onigawara shōkō hoki" 大 宰府式鬼瓦小考補記. Kyūshū Rekishi Shiryōkan kenkyūronshū 29 (2004), pp. 57-62.

Igata Susumu. “Kanzeonji no bonshō” 観世音寺の梵鐘. In Kanzeonji: Kōsatsuhen 観世音寺: 考察編, ed. Kyūshū Rekishi Shiryōkan 九州歴史資料館, pp. 101-108. Kyūshū Rekishi Shiryōkan, 2007.

Igata Susumu. “Seichi Dazaifu no hotoketachi” 聖地太宰府 の仏たち. Kairo 海路 10 (2012), pp. 11-28.

Igata Susumu. “Shiōji to Shitennōzō o tazunete" 四王寺と 四天王像を訪ねて. Nishinihon bunka 西日本文化 453 (2011), pp. 14-17.

Iwato Akiko 岩戸晶子. “Nara jidai no kimenmon onigawara: Kawarafuki gijutsu kara mita Heijōkyūshiki onigawara to nanto shichidaiji-shiki onigawara no hensen” 奈良時代の鬼面文鬼瓦: 瓦莫技術加見た平 城宮式鬼瓦と南都七大寺式鬼瓦の变遷. Shirin 史林 84:3 (2001), pp. 329-68.

Kameda Shūichi 龟田修一. Nikkan kodai kawara no kenkyū 日韓古代瓦の研究. Yoshikawa Kōbunkan, 2006.

Kameda Shūichi. "Kogasen yori mita Dazaifu to Chōsen” 古 瓦㙛より見た大宰府と朝鮮. In Dazaifu kobunka ronsō: Kyūshū Rekishi Shiryōkan kaikan jisshūnen kinen (gekan) 大宰府古文化論叢:九州歴史資料館開館十周年記 念(下巻), ed. Kyūshū Rekishi Shiryōkan, pp. 273-309. Yoshikawa Kōbunkan, 1983.

Kanegae Hiroyuki 鐘江宏之. “Nihon no nanaseiki shi” saikō: Kenzuishi kara Taihō ritsuryō made”「日本の七 世紀史」再考: 遣隋使加大宝律令まで. Gakushūin shigaku 学習院史学 49 (2011), pp. 63-76. 
Kanegae Hiroyuki. Zenshū Nihon no rekishi 3: Ritsuryō kokka to manyō bito 全集日本の歴史 3: 律令国家と万葉 びと. Shōgakkan, 2008.

Kang Ubang 姜友邦. “Han'gug wadang yesullon sŏsŏl” 韓国瓦当芸術論序説. In Silla wajŏn: Arŭmdaun Silla Kiwa, Kŭ Ch'ŏnnyŏn Ǔi Sumkyŏl 新羅瓦塼: 아름다운신라기와, 그천년의숨결, ed. Kungnip Kyŏngju Pangmulgwan 國立慶州博物館, pp. 420-29. Kyŏngju: Kyŏngju Segye Munhwa Eksŭp'o Chojik Wiwŏnhoe, 2000.

Kobayashi Kazuo 小杉一雄. “Onigawara kō” 鬼瓦考. Yumedono 夢殿 18 (1938), pp. 250-6o.

Kungnip Kyŏngju Pangmulgwan 國立慶州博物館, ed. Silla wajŏn: Arŭmdaun Silla Kiwa, Kŭ Ch’ŏnnyŏn Ǔi Sumkyŏl 新羅瓦塼: 아름다운신라기와, 그천년의숨결. Kyŏngju: Kyŏngju Segye Munhwa Eksŭp'o Chojik Wiwŏnhoe, 2000.

Kuno Takeshi 久野健 and Mochimaru Kazuo 持丸一夫. Oshidashibutsu to senbutsu 押出仏と塼仏 (Nihon no bijutsu日本の美術 118 [March 1976]). Shibundo, 1976.

Kurihara Kazuhiko 栗原和彦. “Dazaifu-shiki onigawara, Rōji-shiki nokigawara, Kōrokan-shiki nokigawara” 大 宰府式鬼瓦·老司式軒瓦·鴻臚館式軒瓦. In Ōchōno $k o ̄ k o g a k u$ 王朝の考古学, ed. Ōkawa Kiyoshi Hakushi Koki Kinenkai 大川清博士古稀記念会, pp. 579-94. Yūzankaku, 1995.

Kyūshū Rekishi Shiryōkan 九州歴史資料館, ed. Dazaifu o saguru saiensu 大宰府を探るサイエンス. Kyūshū Rekishi Shiryōkan, 2017.

Kyūshū Rekishi Shiryōkan, ed. Dazaifu Seichō ato 大宰府政 庁跡. Kyūshū Rekishi Shiryōkan, 2002.

Kyūshū Rekishi Shiryōkan, ed. Fukuoka no shinbutsu no sekai: Kyūshū hokubu ni hana hiraita shinkō to zōkei 福 岡の神仏の世界: 九州北部に華開いた信仰と造形. Kyūshū Rekishi Shiryōkan, 2014.

Kyūshū Rekishi Shiryōkan, ed. Kanzeonji: Ibutsuhen vol. 2 観世音寺: 遺物編 2. Kyūshū Rekishi Shiryōkan, 2007.

Morimitsu Toshihiko 毛利光俊彦. “Nihon kodai no kimenmon onigawara: 8-seiki o chūshin toshite” 日本古 代の鬼面文鬼瓦: 8世紀を中心として. Nara Kokuritsu Bunkazai Kenkyūjo gakuhō 奈良国立文化財研究所学 報 38, Kenkyūronshū 研究論集 VI (1980), pp. 29-66.

Oda Fujio 小田富士雄. “Buzen ni okeru Shiragi-kei kawara to sono igi: Kyūshū hakken Chōsen-kei kogawara no kenkyū (1)”豊前に於ける新羅系瓦とその意義: 九州 発見朝鮮系古瓦の研究(一). Shien 史淵 85 (1961), pp. 109-39.
Oda Fujio. "Kyūshū ni okeru Dazaifu-kei kogawara no tenkai (4)”九州に於ける大宰府系古瓦の展開 (4). Kyūshu kōkogaku 九州考古学 13 (1961), pp. 12-13.

Oda Fujio. Shiragi no kogasen 新羅の古瓦塼. Kitakyūshūshi Rekishi Hakubutsukan, 1975.

Ruijū sandaikyaku 類聚三代格, zenhen前編 and kōhen後編, Vols 2-6 and 2-7 (1962) in Shintei zōho kokushi taikei.

Shintei zōho kokushi taikei 新訂増補国史大系. 66 vols. Yoshikawa Kōbunkan, 1929-1964.

Shōgakukan 小学館. Sekai bijutsu zenshū, Tōyō hen, Sangoku Nanbokuchō 世界美術全集 東洋編 三国·南北朝. Vol. 3 . Shōgakkan, 2000.

Sugihara Toshiyuki 杉原敏之. Tō no mikado Dazaifu 遠の 朝廷大宰府. Shirīzu “Iseki o manabu” シリーズ「遺跡を 学ぶ」76. Shinsensha, 2011.

Takeuchi Rizō 竹内理三, ed. Dazaifu, Dazaifu Tenmanḡ shiryō 大宰府·太宰府天満宮史料. Vol. 1. Dazaifu: Dazaifu Tenmangū, 1964.

Tamura Kei 田村啓. “Ijū-zō shōkō: Rokuseiki zenhan sakurei no seishitsu to kinō o chūshin ni” 畏獣像小考: 六世紀 前半作例の性質と機能を中心に. Bijutsushi ronshu 美術 史論集 10 (2010), pp. 103-21.

Tsiang, K., et al. Echoes of the Past: The Buddhist Cave Temples of Xiangtangshan. Distributed by the University of Chicago Press. Chicago: Smart Museum of Art, 2010.

Yamamoto Tadanao 山本忠尚. “Shitadashi jūmen kō” 舌出 し獣面考. Nara Kokuritsu Bunkazai Kenkyūjo gakuhō 35 奈良国立文化財研究所学報 35, Kenkyüronshū V 研究 論集 V (1979), pp. 89-149. 